\title{
Equilar Gender Diversity Index (EGDI)
}

\author{
Heather Griffiths, Yasmin Marshall and Anne Laure Humbert
}

\begin{abstract}
The objective of this chapter is to provide a comprehensive review of the Equilar Gender Diversity Index (EGDI). The EGDI highlights the prevalence of women within the Russell 3000 company board of directors as a response to increasing calls for diversity from investors and other stakeholders. We begin by providing an overview of Equilar as an organisation, before outlining the purpose of the EGDI. We then move on to investigate how the EGDI is structured and the methodology used to construct it. Although the EGDI has a modest usage and awareness, we discuss a handful of academic papers, media articles and a high profile campaign that Equilar and its data are used and cited in before moving on to analyse the strengths and weaknesses of the EGDI. We conclude the article by making suggestions for future uses and how the EGDI can be improved.
\end{abstract}

\section{Introduction}

Women's representation within the labour market has been increasing globally since 1980 . For example in the UK, women's participation in the labour market has grown from $35.9 \%$ in 1980 to $57.5 \%$ in 2016, while in the US women's participation has increased from $51.5 \%$ in 1980 to $56.8 \%$ in 2016 (Ortiz-Ospina and Tzvetkova, 2017). However, whilst there may be more women participating within the paid economy, their representation in powerful, senior roles remains low. Globally, women held only 15\% of all board seats in 2017 (Catalyst, 2018). In the US, only 17.7\% of Russell 3000 corporate board seats were held by women in 2018 (2020 Women on Boards, 2018) and in the UK $26.7 \%$ of the FTSE 350 board seats were held by women in 2018 (Hampton, 2018). Furthermore, when assessing the number of women in board leadership, women hold only $4 \%$ of CEO and board chairs globally (Deloitte, 2017).

Greater board diversity is often positioned as a matter of social justice as well as improving organisational performance. Proponents of social justice argue that gender parity on boards is a more accurate reflection of women's social and economic contribution. Women make up 50\% of the global population (The World Bank Data, 2017) and are often the primary purchasers and controllers of the household budget and spending. It is also argued that women's different experiences, beliefs and perspectives should be adequately and equally represented in the boardroom (Hillman, Shropshire and Cannella, 2007; Seierstad, 2016). The business case for more inclusive company boards often rests on the notion that it improves business performance through diverse thinking and decision making (Hillman, Shropshire and Cannella, 2007; Lückerath-Rovers, 2011). It is also recognised as a key indicator of corporate governance and corporate social responsibility (Hillman, Shropshire and Cannella, 2007; Lückerath-Rovers, 2011). The idea that gender diverse boards improve company performance is a discourse now familiar within the corporate world and part of many equality and corporate governance lexicons. Yet the evidence to support this narrative is inconclusive and contextually shaped. In their meta-analysis of over 140 studies on the relationship between women 
on boards and firm performance, Post \& Byron (2015) found that although companies with more women directors tended to have higher accounting returns this did not necessarily translate into improved market performance. The authors suggest that the impact of women's board representation on market performance depends on the national context, in particular the country's attitude to gender equality and the level of legislative protection offered to company shareholders (Post \& Byron, 2015). Similar results were reported by Hoobler et al. (2018) who also found that the association between women on boards and financial performance was stronger in countries with higher levels of gender equality, arguing for a reconceptualisation of the business case for increasing the number of women on boards.

Persisting inequalities in society, and more specifically in the labour market and organisations, have increasingly been measured through composite indicators that are outlined in this volume. The rationale for such composite measures is to provide a platform for action through metrification and quantification of the problem, but also in the progress made. In this chapter, we focus specifically on the Equilar Gender Diversity Index (EGDI), developed to measure the progress made by top Russell 3000 companies in the US. We first provide an overview of the origin and history of Equilar, the organization behind the development of the EGDI, and the identified purpose of the development of the composite measure. We then outline the methodological steps used to construct the EGDI, the data it relies upon and the rankings that it produces. We then look at how it is applied, and assess its strengths and weaknesses. We conclude with some suggestions for future directions.

\section{Origin and History}

Equilar is a privately owned American organisation founded in 2000 by former management consultant and ex-Vice President of DLJ investment bank, David Chun. Equilar track data on executives from publicly listed companies in the US and the company profits from selling this information to their clients through several data platforms. Their business model is to mine, cleanse and analyse this data and sell it to clients who use the information for the purposes of benchmarking executive pay and board recruitment. These clients number around 1,000 publicly listed organisations in the US, many of whom are in the NASDAQ, including Google, Starbucks and Apple (Nasdaq, 2016). With a foundation in corporate governance, Equilar have recently turned their attention to board diversity, using the data they have collected on executives to create the Equilar Gender Diversity Index (EGDI).

The EGDI was introduced in January 2017 and emerged out of the organisation's Diversity Network created a year earlier. The purpose of the Equilar Diversity Network is to increase the visibility of women and those from an ethnic minority background who are considered 'board ready'. The EGDI tracks the proportion of women on US Russell 3000 companies' executive boards and projects how long it will take to reach gender parity. The measure used in the EGDI reflects the total percentage of Russell 3000 board seats that were occupied by women at the end of each quarter.

The EGDI is calculated every quarter and provides a longitudinal comparison of progress both quarterly and annually. Equilar say that the regularity of their EGDI report and the sample size they draw upon makes their index unique in its ability to reflect the dynamic nature of board composition 
in publicly listed US companies. The quarterly report provides an updated prediction of the year in which Russell 3000 boards will reach gender parity. As discussed in more detail later in the chapter, this prediction lacks methodological rigour but does provide a useful barometer of change. Each issue of the report focuses on a different aspect of gender board parity. Previous examples include the number of new women added to boards, the percentage of boards with at least one woman, a list of boards who have reached gender parity, and the number of boards with women's representation between $40 \%$ and $50 \%$. Equilar say the purpose of this quarterly report is to 'capture the influence of the increasing calls for diversity from investors and other stakeholders in real time' (Equilar, 2019). The report also acts as an informal measure of accountability. The liberal culture of US governance means that board diversity targets are not enshrined in policy, rather they are encouraged only through soft legislation. The EGDI report acts as visible measure of accountability, the results of which are often reported in high profile corporate media outlets.

The EGDI utilises Equilar's extensive database of executive information gathered from over 250,000 publicly listed companies, which it also uses to power its main product 'Equilar BoardEdge'. The data includes detailed information on the directors of executive boards, such as the date at which they started; their age; the total number of women and men directors on the board; the number of other directorships; the company industry; market capitalization; their title within the company and whether the director was on the audit; compensation; corporate governance, or nominating committee (Nili, 2019). It also provides other advanced data such as how board members and companies are connected to each other. When subscribing to BoardEdge, members also get access to the Equilar Diversity Network. This network provides a register of 'board ready executives', heralding from organisations who have demonstrated a commitment to ethnic and gender diversity. The network is led by Equilar's only woman Vice President, Belen Gomez who describes it as a 'consortium', with an aim to 'advance diverse representation in boardrooms across the globe'.

\section{Methodology}

Equilar acquire board data quarterly from changes cited in 8-K filings to the US Securities and Exchange Commission (SEC). As part of the Sarbanes-Oxley Act 2002, publicly listed companies are obliged to file an 8-K form to notify shareholders and potential investors of any events, which may affect share prices. Such events include appointment or departure of directors and certain executive offers, as well as major changes in company operations such as disposal or acquisition of assets or bankruptcy. The 8-K filings are classed as a 'current report' by the SEC as companies are required to submit the report within four business days of the specified event (US Securities and Exchange Commission, 2012).

To update the EGDI, Equilar integrate the 8-K filings with existing data they hold on executives to produce a quarterly measure of gender board diversity. At the end of every quarter, Equilar calculate the percentage of women board directors in the Russell 3000 and convert this into an index measure from zero to one, with zero being a complete absence of women and one representing gender parity. The index is a basic calculation where the total percentage of women on boards is divided by 50 to get an index measure between zero and one. At the time of writing, the EGDI had reached 0.40 and if this index were to reach 1, gender parity would have been achieved (on average) across all Russell 3000 
companies. If women were to outnumber men on Russell 3000 boards then the index score would go beyond 1. Although this goal has not yet been met, several individual companies are in this situation (see Table 1) and as an illustration, Tootsie Roll Industries Inc would achieve a of score 1.5 on the index. If all Russell 3000 companies had women only executive boards, the index would reach a score 2, which is the maximum available by design. Equilar present their GDI using an illustration of a speedometer where the number ' 1 ' is placed at a 90-degree angle in the middle and although it is not labelled, the number ' 2 ' would be at 180- degrees from zero. Figure 1 is extracted from the EGDI Q4 2018 as an example.

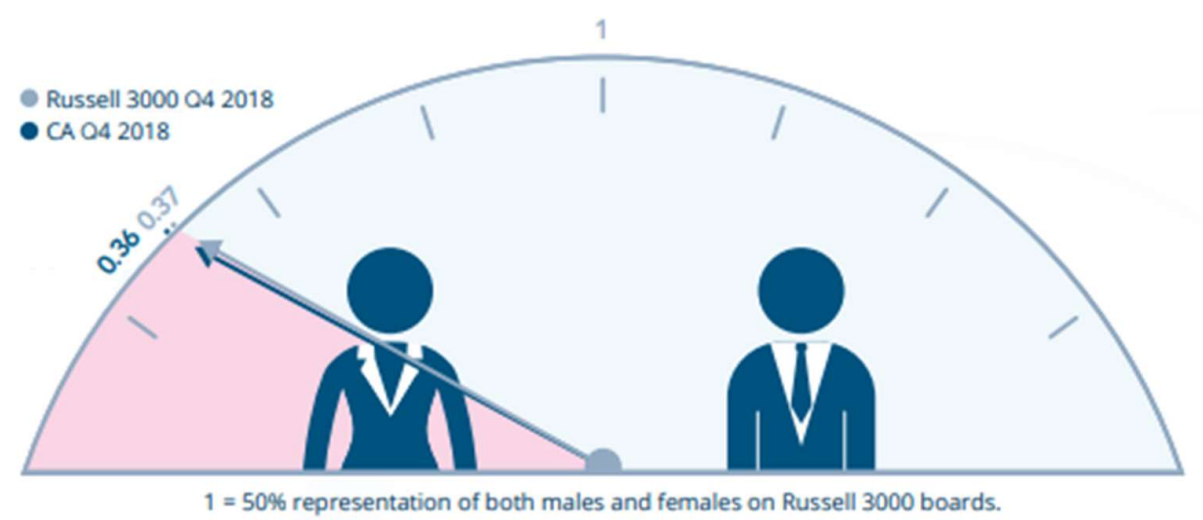

Figure 1 Source: Equilar EGDI Report Q4 2018

Comparing Figure 1 to the illustration of the EGDI in Q1 2017 in Figure 2, the EGDI score has increased by 0.05. Therefore, between Q1 2017 and Q4 2018, the number of women on boards increased by 2.5 percentage points.

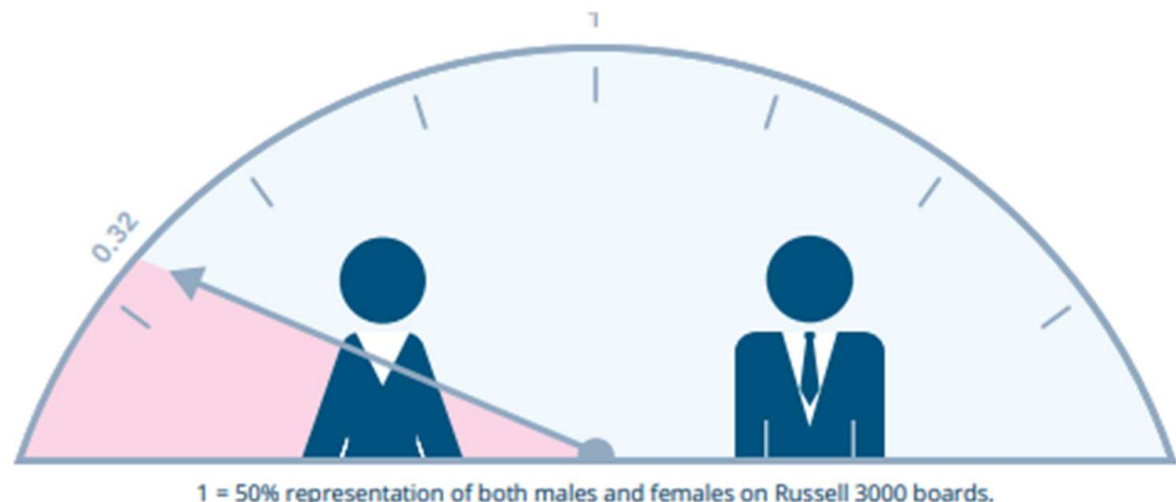

Figure 2 Source: Equilar Gender Diversity Index Q2 2017]

Equilar also extrapolate the year that gender parity will be achieved based on the growth rate or yearon-year percentage increase of women on boards. Back in Q4 2016, parity across Russell 3000 boards 
was expected to be achieved by 2055. As of Q4 2018, this reduced to 2034 suggesting that companies were speeding up efforts to improve gender representation on their boards. However, this extrapolation of the results lacks methodological robustness and so these dates should be regarded as indicative only and treated with caution.

\title{
Achieving Gender Parity
}

\author{
Q4 $2018 \rightarrow 2034$ \\ Q4 $2017 \rightarrow 2048$ \\ Q4 $2016 \rightarrow 2055$
}

EQUILAR

Gender Diversity Index (GDI)

Figure 3 Source: Equilar Q4 2018 Gender Diversity Index

Equilar also use their EGDI to produce a list of the Russell 3000 companies who have already reached gender parity on their boards. Lists have been released annually in the Q2 2017 and Q2 2018 EGDI reports. Some observations from these tables include how the number of Russell 3000 boards to reach gender parity increased from 24 in Q2 2017 to 39 in Q2 2018. Many boards' representation remained stable, notably with Tootsie Roll Industries Inc. having the highest representation of women on their board at $75 \%$. During this period, 21 new companies from the Russell 3000 reached gender parity on their boards. However, it is also important to note that six companies from the Q2 2017 table were not featured in the Q2 2018 update, showing that these companies had actually lost women from their boards. As of August 2018, only 39 out of 3000 companies had reached gender parity on their boards, amounting to only $1.3 \%$, showing that there is still an enormous amount of work to do. This is a stark reminder that the EGDI calculation, of the total number of women on Russell 3000 boards, presents a much more positive picture of progress but it is only an average across all companies. This is why it is important that Equilar continue to contextualise the EGDI with the progress made at individual company level. However, as will be explored later, these rankings only celebrate those who have achieved or exceeded gender parity and offer very little critique of those majority companies who appear stubborn to change. 


\begin{tabular}{|c|c|c|c|}
\hline \multicolumn{4}{|l|}{ Q2 2018} \\
\hline Company & $\begin{array}{c}\text { Board } \\
\text { Members }\end{array}$ & $\begin{array}{l}\text { Numbers of } \\
\text { Women }\end{array}$ & \% Women \\
\hline TOOTSIE ROLL INDUSTRIES, INC. & 4 & 3 & $75.0 \%$ \\
\hline CONNECTICUT WATER SERVICE, INC. & 9 & 6 & $66.7 \%$ \\
\hline EXPONENT, INC. & 6 & 4 & $66.7 \%$ \\
\hline BUILD-A-BEAR WORKSHOP, INC. & 7 & 4 & $57.1 \%$ \\
\hline $\begin{array}{l}\text { NAVIOS MARITIME ACQUISITION } \\
\text { CORPORATION }\end{array}$ & 7 & 4 & $57.1 \%$ \\
\hline ALLIANT ENERGY CORPORATION & 9 & 5 & $55.6 \%$ \\
\hline CASEY'S GENERAL STORES, INC. & 9 & 5 & $55.6 \%$ \\
\hline CHICO'S FAS, INC. & 9 & 5 & $55.6 \%$ \\
\hline E.L.F. BEAUTY, INC. & 9 & 5 & $55.6 \%$ \\
\hline NAVIENT CORPORATION & 9 & 5 & $55.6 \%$ \\
\hline VIACOM, INC. & 9 & 5 & $55.6 \%$ \\
\hline CALERES, INC. & 11 & 6 & $54.5 \%$ \\
\hline OMNICOM GROUP INC. & 11 & 6 & $54.5 \%$ \\
\hline SIGNET JEWELERS LIMITED & 11 & 6 & $54.5 \%$ \\
\hline SLEEP NUMBER CORPORATION & 11 & 6 & $54.5 \%$ \\
\hline ABERCROMBIE \& FITCH CO. & 8 & 4 & $50.0 \%$ \\
\hline AMERICAN WATER WORKS COMPANY, INC. & 8 & 4 & $50.0 \%$ \\
\hline AUTODESK, INC. & 8 & 4 & $50.0 \%$ \\
\hline BEST BUY CO., INC. & 10 & 5 & $50.0 \%$ \\
\hline BLOOMIN' BRANDS, INC. & 8 & 4 & $50.0 \%$ \\
\hline CALITHERA BIOSCIENCES & 8 & 4 & $50.0 \%$ \\
\hline COMPX INTERNATIONAL INC. & 8 & 4 & $50.0 \%$ \\
\hline
\end{tabular}




\begin{tabular}{|c|c|c|c|}
\hline CYS INVESTMENTS, INC. & 6 & 3 & $50.0 \%$ \\
\hline ETSY, INC. & 8 & 4 & $50.0 \%$ \\
\hline LIBBEY INC. & 8 & 4 & $50.0 \%$ \\
\hline MACY'S, INC. & 10 & 5 & $50.0 \%$ \\
\hline MONOTYPE IMAGING HOLDINGS INC. & 8 & 4 & $50.0 \%$ \\
\hline NOBLE CORPORATION PLC & 6 & 3 & $50.0 \%$ \\
\hline PAPA JOHN'S INTERNATIONAL, INC. & 6 & 3 & $50.0 \%$ \\
\hline RED ROBIN GOURMET BURGERS, INC. & 8 & 4 & $50.0 \%$ \\
\hline RUTH'S HOSPITALITY GROUP, INC. & 6 & 3 & $50.0 \%$ \\
\hline SPIRE INC. & 8 & 4 & $50.0 \%$ \\
\hline TREVENA, INC. & 8 & 4 & $50.0 \%$ \\
\hline TUPPERWARE BRANDS CORPORATION & 12 & 6 & $50.0 \%$ \\
\hline ULTA SALON, COSMETICS \& FRAGRANCE & 12 & 6 & $50.0 \%$ \\
\hline VIVEVE MEDICAL, INC. & 6 & 3 & $50.0 \%$ \\
\hline WYNN RESORTS, LIMITED & 8 & 4 & $50.0 \%$ \\
\hline ZENDESK, INC. & 8 & 4 & $50.0 \%$ \\
\hline ZYNGA INC. & 8 & 4 & $50.0 \%$ \\
\hline
\end{tabular}

Table 1 Source: Equilar Q2 2018 Gender Diversity Index [waiting copyright permission]

\section{Applications}

Although the EGDI is not explicitly cited in academic texts, Equilar's data have been used in a number of academic publications. All publications are concerned with gender diversity and women's representation on boards and use Equilar's data in their methodologies to comment on the number and proportion of women on corporate boards. Tinsley et al (2017) acquired board data from Equilar to theorise that women often obtain board positions through 'gender matching' where women are appointed to a corporate board to replace another woman. Whilst Tinsley et al's (2017) work is the only publication we found where Equilar's raw data were used as part of a research project. Equilar's own statistical analysis on gender equality has been cited in work emanating from some of America's biggest law schools (e.g. Grundfest, 2018; Nili, 2019; Nili \& Rosenblum, 2019) and has even made it as 
far as Master's thesis on gender diversity and compensation on company boards in Norway (Jore \& Aase, 2018). In his evaluation of the position and influence of women on boards, Nili (2019) uses Equilar's BoardEdge, their flagship product for disseminating data to clients. This is combined with analysis from the quarterly EGDI reports to examine the roles and responsibilities of women on boards and the tenure and 'clout' they have within the board room. His article looks at how many women hold leadership positions on boards along with how much they participate and influence decisions made by boards. Grundfest's (2018) paper discusses California's SB 826 legislation - that requires publicly listed Californian companies to have at least one woman on the board by the end of 2019 and how the subsequent outcome means that the increase in board seats for women will be trivial. Grundfest's work also uses the EGDI report rather than the EGDI measure to demonstrate the percentage of women on Fortune 500 and Russell 3000 boards.

This handful of recent research papers suggests that Equilar's data on gender diversity is gaining traction within small sub-sectors of the academic community but their biggest impact remains in the US business media. The company actively work with the media (Nasdaq, 2016) to promote their findings and engage in topical discussions around gender equality in the boardroom. Their work is credited in articles from The Washington Post, The Wall Street Journal and USA Today, to name a few, yet the EGDI is rarely mentioned. Whilst Equilar's work on gender equality is receiving growing recognition, the index itself is yet to capture the imagination of reporters or campaigners. It is unclear whether journalists are overlooking the EGDI in favour of more newsworthy statistics or whether Equilar themselves are not actively promoting the index. Media articles tend to focus on digestible and debateable findings, such as the percentage of companies who have no women on their boards (e.g. Ivanova, 2018 for CBS News; Guynn, 2017 for USA Today) or how long Equilar predict it will take to reach gender parity (Green, 2019 for Bloomberg). Equilar's data are also used by media sources to corroborate the findings of other, more high-profile research or referenced alongside the work of other research companies who engage in similar work. The frequency with which Equilar are cited within the US media suggests they are building a strong reputation for being a 'go-to' source for data on gender diversity in the boardroom. Yet, despite this, the EGDI itself receives little or no press coverage in the corporate or mainstream media outlets.

As well as having a growing presence in the US business media, the EGDI has also caught the attention of one high-profile campaign in the US that promotes more women on company boards. The 2020 Women on Boards campaign (2020 WOB) have used Equilar's data for two of their publications. The 2020 WOB campaign is a not-for-profit organisation that developed out of frustration with the lack of women on corporate boards. The president and co-founder of the organisation, Stephanie Sonnabend, is a former CEO of Sonesta Hotels and currently sits on two public boards. Along with Malli Gero, she founded 2020 WOB in 2010 with the objective to raise awareness of women's underrepresentation and ultimately increase the percentage of women on corporate boards in the US to $20 \%$ or more by 2020 .

As a campaign, 2020 WOB have their own Gender Diversity Index, which is released on an annual basis. They began their focus on Fortune 1000 companies but once women held $20 \%$ of board seats within these companies, they partnered with Equilar and shifted their attention to Russell 3000 companies. The partnership between Equilar and the 2020 WOB campaign was announced in the fifth (2017) Gender Diversity Index report by the 2020 WOB campaign. This report focused on key findings from 
the campaign on the Fortune 1000 boards and introduced their next goal of increasing women's representation on Russell 3000 boards (2020 Women on Boards, 2017). The following WOB Gender Diversity Index in 2018 focused on women's representation on Russell 3000 using data and research provided by Equilar, some of which was created exclusively for the campaign (2020 Women on Boards, 2018). The 2020 WOB campaign boasts accreditation and sponsorship from large US organisations such as American Express, Bank of America, FedEx and PwC, along with having a reputable board of leaders from diverse and influential companies such as Harvard and Deloitte. However, it is important to note that like their contemporaries in academia, 2020 WOB do not use the EGDI and instead use Equilar's main database to create their own statistical analysis and indices.

\section{Strengths and Weaknesses}

In the following section, we assess the strengths and weaknesses of the EGDI to understand how impactful the index is, before suggesting future directions and improvements that could be made.

\section{Strength: longitudinal data}

One of the EGDI's greatest advantages is that it is calculated regularly and consistently meaning that comparisons can be made over time. Equilar's EGDI reports always emphasise this aspect of the data by comparing how the percentage of women on boards has changed compared to the previous quarter. Now that the index is entering its third year, they can also make regular annual comparisons. As well as tracking changes in the EGDI over time, the report also comments on how projections toward gender parity are improving both quarterly and annually. For example, in 2017 Q4, Equilar predicted gender parity on Russell 3000 boards would not be reached until 2048. A year later, they were able to amend this projection to 2034 since their data suggested gender equality was improving at a faster rate than had been originally anticipated. However, as stated earlier in the chapter, these extrapolations are only indicative and not methodologically robust, but they do provide a powerful statement on the trajectory and speed of change and communicate the necessity and urgency for change to happen.

\section{Strength: subscription-free resource}

Although the EGDI has received little attention in the media or academia, Equilar appear committed to producing regular, quarterly EGDI reports that they make freely available to the public. Each report takes a different focus (see above), consistently giving an updated projection on board gender parity using the revised index measure as the main headline to the report. This subscription-free access means the index and it accompanying infographics are accessible to all. Although as implied above, awareness of the EGDI is low so it is questionable as to how valuable these regular reports are to those outside the organisation. As the EGDI become established, it might gain higher visibility and become a valuable resource for educators or campaigners for gender diversity as the presentation of the data, using bold infographics, makes the findings easily digestible for non-specialist audiences. 


\section{Strength: local interests}

Equilar's headquarters are in Redwood City, California and the EGDI reports often include data relevant to their locale. This acts to position Equilar as a company invested in gender diversity at a state as well as national level, something which is reflected in the way the company engage in local corporate governance issues and policy debate. In September 2018, the State of California passed legislation (SB826) that required publicly listed companies headquartered in California to have a minimum of one woman on its board of directors by December 31, 2019. By 31 December 2021, companies with five directors are required to have at least two women board members and companies with six directors must achieve gender parity (Equilar, 2019). Equilar responded by producing a special version of the EGDI and a report that included the gender board diversity of Californian companies featured in the Russell 3000. As the issue and awareness of women on boards continues to gain traction and importance, there is the possibility that other States in the US will follow suit. Equilar therefore have an opportunity to create regular EGDIs and reports for California and other States that implement gender specific laws, to compare and contrast how States are doing in proximity to each other.

\section{Weakness: Lack of intersectional analysis}

Equilar appear to be aware that as part of their diversity agenda, issues of racial and ethnic inequality on boards need to be given as greater priority as gender (Equilar, 2016). However, there is no evidence that their promotion of diversity recognises the intersection between gender and race (nor other social inequalities) in the EGDI or on the accompanying reports, neither is there any indication that this will be addressed in the future. Whilst we applaud the work Equilar are doing to highlight gender inequality on company boards we believe they could do more to include measures of race and ethnicity within their data outputs. Equilar's Diversity Network (EDN) has been set-up to 'advance diverse representation in boardrooms' (Equilar, n.d.) which suggests that the company possess data on ethnicity as well as gender. As a Korean immigrant, Equilars' founder David Chun, says he recognises that some members of society struggle more than others and he considers it his responsibility to 'help others' and 'share what [he's] learnt' (Asian Pacific Fund, n.d.).

Currently, data on executive and board ethnic diversity is less readily available than it is on gender, perhaps because it is more politically sensitive and considered harder to measure (as gender is still frequently analysed in binary terms despite efforts to recognise its fluidity - see below). The suppression of racial diversity in favour of gender equality may also be a business decision. The US has a troubled history of race relations and racial tensions are still high in many political and geographical arenas. Gender equality on boards is a relatively safe area of diversity in terms of political and economic positioning, and is embraced by many nations across the world as a measure of improving diversity in business. However, many feminist scholars argue that measuring women on boards is an elitist form of diversity and detracts from more pressing issues facing women in the workplace and across society as a whole (e.g. Brown and Kelan, 2020; Humbert, Kelan and Clayton-Hathway, 2019). Whilst Equilar are building their reputation as a reliable source of data on gender equality issues at board level, integrating measures of ethnic diversity could be considered a dilution of this business strategy. Equilar's area of expertise is providing data for executive compensation and recruitment and the EGDI is a spin-off from their core business. Nonetheless, as demonstrated earlier there is a demand for data and commentary in this area of gender equality and Equilar are capitalising on a current gap in that market. 


\section{Weakness: gender as a binary term}

The EGDI assumes gender is a binary term and it is unclear whether this is a limitation of the data or Equilar's interpretation of the data available. Although the number of Russell 3000 board members identifying as non-binary is likely to be very small, Equilar could consider acknowledging this omission and commit to working toward improving the quality of both the data and how it is interpreted. This stance would also reinforce their commitment to diversity and inclusion without detracting from their motivation to improve women's representation on boards. If it is a limitation of the data, Equilar could use their influence within the media and corporate governance world to highlight this as a diversity and inclusion issue and encourage more progressive data collection methods in the future.

Whilst this approach would be applauded by those working in equality, diversity and inclusion spaces, it would counter current trends in US data collection even at the highest level. Despite lobbies from the pressure groups and inside Congress, the Census Bureau were resolute that there would be no questions on gender identity in the 2020 Censure and sex would only be recognised within female/male binary categories (O'Hara, 2017; see also Census.gov). As a profit making company working within these cultural constraints, Equilar would be making a bold stance to recognise gender non-conforming board members as part of their EGDI. Yet, it could also set them apart from their competitors by demonstrating their commitment to current and future issues of board diversity and inclusive management.

\section{Weakness: corporate bias}

Equilar is a privately owned company who operate for profit and their business model is to sell the data they have analysed to their clients. They have created a multitude of products that utilise this data for different purposes and as a private company they are driven by profit and growth. Whilst it may be supported by good intentions, the EGDI is a tool that can be used by Equilar to promote their work and add another dimension to their product base. They have been able to capitalise on the growing trend within the US to improve gender equality, predominantly for an economic rather than a social good. Although evidence in this area shows mixed results (Post \& Byron, 2015), a common argument for gender diverse boards is that it is more profitable for businesses. Despite a lack of evidence, this discourse has seeped into corporate consciousness and is encouraging organisations to adopt a social attitudinal shift toward gender inclusivity in business. These companies represent Equilar's client base so offering them tools to improve board diversity makes good business sense.

However, herein lies an inherent bias in the way Equilar report their analysis around gender on boards. There is considerable overlap between the organisations who make up their client base and those whose board data is included in the EGDI. Whilst this bias does not affect the EGDI calculation, it does discourage Equilar from taking a stronger stance against organisations who fail to promote gender diversity on their boards. So far, the company's tactic has been to celebrate individual companies who are working to improve their board diversity (see above) but anonymise those who are failing to take action. A stronger stance would be to 'name and shame' organisations that have few or no women on their boards and risk losing them as paying clients. Equilar would then be making a bold statement that they will only do business with companies who share their commitment to diversity and inclusion. This may adversely affect the reputation of the worst performing companies thus encouraging them to improve their board diversity more quickly. This bias should not detract from the benefits of the 
index or wider EGDI report but it means that currently, Equilar's stance on board diversity can only ever be a cautious one.

\section{Weakness: no indication of board positions}

While it is useful to understand how many women sit on each of the Russell 3000 boards, Equilar could strengthen the EGDI by illustrating the positions and roles women hold on boards, to understand how much influence they have on decision making. In particular, there is no clear distinction on whether these board positions are executive or non-executive. Executive directors are involved with the dayto-day management of the company and have an in depth knowledge of the business. They are responsible for ensuring that the company information put before the board is completely accurate. Conversely, a non-executive director does not have daily dealings with the management of the company and are only tasked with 'providing objective judgement independent of management on issues facing the company' (Deloitte, 2014).

Some argue that it is more difficult for women to become executive directors than non-executive directors (Daily et al, 1999; Li and Wearing, 2004; Singh et al, 2001) and only 5.1\% of CEOs in the Russell 3000 are women (Guerard, 2018). Formal leadership positions or 'clout titles' (Singh et al, 2001, pp.211) across both executive and non-executive directors, such as Chairperson/President, ViceChairperson/President, CEO, COO and CFO, carry significant power. For example, the Chairperson controls 'the board or committee's agenda in addition to other formal and informal powers' (Nili, 2019, p.182). Furthermore, there is also a matter of status. Leadership positions also symbolise and signal the importance of a director, showing them to be highly respected and valued (ibid, p.182). Executive directors, such as CEOs, tend to hold more power than non-executive directors (Li and Wearing, 2004) and the pathway to becoming a CEO is much harder for women as 'successor CEOs are overwhelmingly selected from high-ranking executives of the focal firm' (Daily et al, 1999, p.94). In order for this to happen, women are often required to 'have line experience in areas such as marketing or operations and typically they need to be offered this experience by mid-career at the latest to be considered in the pipeline for the top position' (Oakley, 2000, p.323). As women face additional barriers to their career progression, such as taking time off to have children, difficulties gaining international experience, finding mentors and senior sponsorship, it is often hard to attain the experience needed by mid-career in order to become executive directors (Singh et al, 2001). It is therefore important to grasp exactly how much influence women have on boards in order to tackle the larger picture of gender equality. This would include examining data on women directors of Russell 3000 companies at a much more granular level by observing and recording how many women sit within the top and most powerful board positions. Equilar could develop their EGDI by distinguishing and reporting how many women executive directors there are along with the number of women nonexecutive directors. 


\section{Future Directions}

\section{Greater promotion of the EGDI}

Accessing the EGDI is not particularly easy or forthcoming. It is not advertised on Equilar's website homepage. The only way to access it is through the Equilar Diversity Network webpage and it could be advantageous to have a central hub for the EGDI on their website. Equilar could also promote and raise awareness of the EGDI a number of ways. For instance, they could circulate the quarterly report via email to subscribers or to partners who support their diversity network, such as 'Catalyst', 'KPMG' and the ' $30 \% \mathrm{Club}^{\prime}$ '. Another way to promote the EGDI would be to leverage these relationships and ask the partners to advertise the EGDI on their webpages. As stated above, Equilar also have a number of well-known media connections such as 'Bloomberg', 'The Wall Street Journal' and the 'Financial Times'. Similar to their diversity network partners, they could also use these connections to raise awareness of the EGDI as distinct from the analysis in the EGDI quarterly report.

\section{Awareness of broader, intersecting diversity issues}

The Equilar's Diversity Network recognises that company boards lack both gender and ethnic diversity but there is no equivalent ethnicity index to the EGDI. Neither does the EGDI recognise intersecting gender inequalities. Doing so would make the EGDI truly unique as the majority of the boardroom analysis in the US measures diversity by gender or race, as if the two were mutually exclusive. Such a move would strengthen Equilar's commitment to board diversity and complement their EDN product. Work is being done in this area, for example the 2019 Missing Pieces Report (DeHaas, D., Akutagawa, L., Spriggs, S., \& Deloitte LLP, 2019) by Harvard Law School and PwC which analysed the progress of women and minorities' representation of boards. Also in 2019, Reuters (Kerber, R. \& DiNapoli, J., 2019) commissioned ISS to run a similar report on the Russell 3000 suggesting there is an increasing appetite for a broader definition of diversity in board composition reporting. By recognising ethnicity and race as part of the EGDI, Equilar could position themselves at the forefront of this shifting conceptualising of diversity reporting and truly present something distinctive in their field.

\section{Gendered language and dissemination}

The EGDI reports use bold infographics to display the data and the statistics they highlight are both practical and accessible. However, these same infographics imply that whilst Equilar may be experts in board gender diversity, they still adhere to social norms around gender, either consciously or unconsciously. Firstly, every report uses a colour theme of pink and blue with, predictably, blue for the data on men and pink for the data on women. This technique is still commonplace in many arenas of gender reporting with many no doubt arguing that it makes the findings easy to read at a glance and is not intended to recreate gender stereotypes. However, we would like to see a professional organisation like Equilar challenge this somewhat outdated and binary approach to reporting on

gender. Alternative colours and symbols could be used to create a similar effect without losing the emphasis on gender difference.

Secondly, the language used to describe the EGDI is based on the masculine metaphor of driving and cars. We recognise this is probably unintentional but nevertheless, it is a strong example of how unconscious gender bias is embedded in organisational practices at all levels. The image of the needle 
on the speedometer (see Figure 1) is considered an integral part of the EGDI reporting and works well to indicate how far there still is to go to reach gender parity. For this reason, we would not necessarily suggest Equilar abandon this imagery but they could perhaps consider the language used alongside it. For example, the EGDI Q4 2018 index included the description that the 'acceleration once again moved the needle' (Equilar, 2019) toward gender parity and in Q2 2017 the EGDI was 'stalling on its slow climb' (Equilar, 2017). Whilst this language complements the metaphor of the speedometer it could be tempered toward a more feminine or gender-neutral representation of growth. These two critiques may seem trivial but if Equilar are truly passionate about advancing gender diversity on boards and across the corporate world, these subtleties matter.

\section{Summary}

The methodology behind the EGDI is incredibly simple but it sends a powerful message. This means the premise of the measurement and the accompanying prediction of gender parity could be adopted across many other similar scenarios, by Equilar and others. We advise caution, however, in using basic extrapolation methods to predict future gender parity but recognise this is an effective technique for communicating the rate and trajectory of change. As discussed above, the EGDI could easily be converted to incorporate a measurement of racial diversity on Russell 3000, which could also include analysis disaggregated by sex. The EGDI could also incorporate an analysis by industrial sector or geographical location to recognise the areas of the economy that are closest to achieving gender parity on boards. Equilar's reports include some original analysis every quarter and with more investment the index has the potential to include some more imaginative and ground-breaking revelations about the board diversity landscape in the US. 


\section{References}

2020 Women on Boards, (2017). 2017 Gender Diversity Index. Retrieved from https://www.2020wob.com/sites/default/files/2020WOB GDI Report 2017 FINAL.pdf

2020 Women on Boards, (2018). 2018 Gender Diversity Index. Retrieved from https://www.2020wob.com/sites/default/files/2020WOB GDI Report 2018 FINAL.pdf

Asia Pacific Fund (n.d.). 'David Chun'. Retrieved from: http://asianpacificfund.org/board/david-chun/ Accessed 28/06/19.

Brown, S., Kelan, E. K. (2020). Gender and Corporate Boards. New York: Routledge, https://doi.org/10.4324/9781315624266

Catalyst. (2018). Quick Take: Women on Corporate Boards. Retrieved from https://www.catalyst.org/research/women-on-corporate-boards/

Census.gov. (2018). 2020 Census Questionnaire. Retrieved from: https://census.gov/programssurveys/decennial-census/technical-documentation/questionnaires/2020.html Accessed: 17/01/20.

Daily, C.M., Certo, S.T., \& Dalton, D.R. (1999). A Decade of Corporate Women: Some Progress in the Boardroom, None in the Executive Suite. Strategic Management Journal, 20 (1), 93-99.

DeHaas, D., Akutagawa, L., Spriggs, S., \& Deloitte LLP (2019) Missing Pieces Report: The 2018 Board Diversity Census of Women and Minorities on Fortune 500 Boards. Harvard Law School Forum on Corporate Governance and Financial Regulation. Retrieved from:

https://corpgov.law.harvard.edu/2019/02/05/missing-pieces-report-the-2018-board-diversitycensus-of-women-and-minorities-on-fortune-500-boards/ Accessed 28/06/19.

Deloitte. (2014). The Different Types of Directors. Retrieved from https://www2.deloitte.com/za/en/pages/governance-risk-and-compliance/articles/the-differenttypes-of-directors.html

Deloitte. (2017). Women in the boardroom, a global perspective: fifth edition. Retrieved from https://www2.deloitte.com/uk/en/pages/risk/articles/women-in-the-boardroom5th-edition.html

Equilar. (2016) 'Equilar Diversity Network Launches to Help Build the Best Boardrooms'. Retrieved from: https://www.equilar.com/press-releases/55-equilar-launches-equilar-diversity-network.html Accessed: 28/06/19.

Equilar. (2017). 'Equilar Gender Diversity Index: Q2 2017' Retrieved from:

https://www.equilar.com/reports/50-gender-diversity-index-q2-2017.html Accessed 28/06/19. 
Equilar. (2019). 'Equilar Q4 2018 Gender Diversity Index'. Retrieved from

https://www.equilar.com/reports/62-equilar-q4-gender-diversity-index.html

Equilar (n.d.) 'Equilar Diversity Network'. Retrieved from: https://www.equilar.com/diversity.html. Accessed 28/06/19.

Green, J. (2019) 'Mary Barra Will Lead the Auto Industry's First Majority-Female Board' Retrieved from: https://www.bloomberg.com/news/articles/2019-04-18/gm-s-barra-to-lead-auto-industry-sfirst-majority-female-board Accessed 28/06/19.

Grundfest, J.A. (2018). 'Mandating Gender Diversity in them Corporate Boardroom: The Inevitable Failure of California's SB 826', Rock Center for Corporate Governance at Stanford University Working Paper No. 232; Stanford Public Law Working Paper.

Guerard, K. (2018). Which Russell 3000 Sectors Rank Highest in Terms of Gender Diversity in Leadership Positions? Retrieved from https://insight.factset.com/which-russell-3000-sectors-rankhighest-in-terms-of-gender-diversity-in-leadership-positions

Guynn, J. (2017) 'Women can't crack the glass ceiling when it comes to tech boards' Retrieved from: https://eu.usatoday.com/story/tech/2017/08/25/women-missing-tech-boards/598706001/

Accessed 28/06/19.

Hampton, P. (2018), 'FTSE women leaders: Hampton-Alexander review' Retrieved from https://www.gov.uk/government/publications/ftse-women-leaders-hampton-alexander-review

Hoobler, J. M., Masterson, C. R., Nkomo, S. M., \& Michel, E. J. (2018). The business case for women leaders: Meta-analysis, research critique, and path forward. Journal of Management, 44(6), 24732499.

Humbert, A. L., Kelan, E. K., \& Clayton-Hathway, K. (2019). 'A rights-based approach to board quotas and how hard sanctions work for gender equality'. European Journal of Women's Studies, 1350506819857125.

Ivanaova, I. (2018) 'Nearly 100 California companies have no women on their board of directors' Retreived from: https://www.cbsnews.com/news/nearly-100-california-companies-have-no-womenon-board-of-directors/ Accessed 28/06/19.

Jore, H.L. and Aase, U.R.S. (2018) 'Gender Diversity on the Board of Directors and CEO Compensation in Norway'. Master's Thesis. BI Norwegian Business School: Handelshøyskolen BI.

Kerber, R. \& DiNapoli, J. (2019). 'Diversity in the 'man cave': Boardrooms gain women as minorities lag'. Reuters Retrieved from: https://www.reuters.com/article/us-usa-directors-diversity/diversityin-the-man-cave-boardrooms-gain-women-as-minorities-lag-idUSKCN1Q20E8 Accessed 28/06/19. 
Li, C.A. \& Wearing, B. (2004). Between glass ceilings: Female non-executive directors in UK quoted companies. International Journal of Disclosure and Governance, 1(4), 355-371.

Lückerath-Rovers, M. (2013). Women on boards and firm performance. Journal of Management and Governance, 17(1), 491-509.

Nasdaq. (2016) 'David Chun, CEO of Equilar, Inc. answers your questions before he rings the Nasdaq Closing Bell!' Retrieved from: https://www.facebook.com/Nasdaq/videos/david-chunceo-of-equilar-inc-answers-your-questions-before-he-rings-the-nasdaq-/10154016491262429/ Accessed 28/06/19.

Nili, Y.G. (2019). Beyond the Numbers: Substantive Gender Diversity in Boardrooms. Indiana Law Journal, 94(1), 145-202.

Oakley, J. G. (2000). Gender-based barriers to senior management positions: Understanding the scarcity of female CEOs. Journal of Business Ethics, 27, 321-334.

Ortiz-Ospina, E. and Tzvetkova, S. (2017). Working women: Key facts and trends in female labor force participation. Retrieved from https://ourworldindata.org/female-labor-force-participation-key-facts

O'Hara, M. E. (2017). LGBTQ Americans Won't Be Counted in 2020 U.S. Census After All. Retrieved from: https://www.nbcnews.com/feature/nbc-out/lgbtq-americans-won-t-be-counted-2020-u-scensus-n739911 Accessed: 17/01/20.

Post, C., \& Byron, K. (2015). Women on boards and firm financial performance: A metaanalysis. Academy of Management Journal, 58(5), 1546-1571.

Seierstad, C. (2016). Beyond the Business Case: The Need for Both Utility and Justice Rationales for Increasing the Share of Women on Boards. Corporate Governance: An International Review, 24(4), 390-405.

Singh, V., Vinnicombe, S., and Johnson, P. (2001). Women Directors on Top UK Boards. Corporate Governance, 9(3), 206-216.

Tinsley, C.H., Wade, J.B., Main, B.G.M. AND O'Reilly, C.A. (2017). Gender Diversity on US Corporate Boards: Are We Running in Place? ILR Review, 70(1), 160-189.

US Securities and Exchange Commission. (2012). 'Form 8-K' Retrieved from: https://www.sec.gov/fast-answers/answersform8khtm.html Accessed 28/06/19.

The World Bank Data, (2017). Population, female (\% of total). Retrieved from https://data.worldbank.org/indicator/SP.POP.TOTL.FE.ZS 